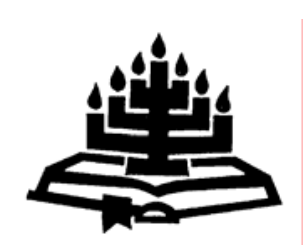

\title{
Die intensiteit van die Semi-Pelagiaanse stryd in die Galliese Kerk van die vyfde en sesde eeu
}

\author{
Rikus Fick \\ Skool vir Kerkwetenskappe \\ Potchefstroomkampus \\ Noordwes-Universiteit \\ POTCHEFSTROOM \\ E-pos: Rikus.Fick@nwu.ac.za
}

\begin{abstract}
The intensity of the Semi-Pelagian controversy in the Gaulish Church of the fifth and sixth centuries
\end{abstract}

The controversy over Augustine's predestinarian views was transferred to Gaul after the Vandal conquest of Africa. The Pelagian controversy was characterised by the participation of several prominent figures and the convention of seven councils. The question, however, is why the Semi-Pelagian controversy was of such a different character. The answer is to be found in the context of the participants in the debate: the unique character of the Gaulish Church, the influence from the monasteries and the distinctive political setting of this region. John Cassian, founder of the monasteries of Marseilles, took the view that God's grace comes as an answer to the beginning of a good will in the human person and the free will in man can either neglect or delight in the grace of God. The same sentiments were soon heard from the monastery on the island of Lerins. The reaction to this stance by Prosper of Aquitaine led to the literary involvement of Augustine. For several decades the bishops of Arles and Vienne attempted to raise their city's ecclesiastical status above the other cities of Southern Gaul - a phenomenon typical of the public life of this region. In 529 Caesarius, former monk of Lerins, of aristocratic descent and bishop of Arles, held a synod at Orange. This synod affirmed a diluted form of the Augustinian position. All the elements of the character of this controversy can be found in the person of Caesarius who was also mainly responsible for the formulation of the canons of this synod. 


\section{Opsomming}

\section{Die intensiteit van die Semi-Pelagiaanse stryd in die Galliese Kerk van die vyfde en sesde eeu}

Die stryd rondom Augustinus se sienings oor die uitverkiesing het na die Vandaalse inval in Noord-Afrika na Gallië oorgewaai. Die Pelagiaanse stryd is gekenmerk deur die betrokkenheid van verskeie prominente figure en die vergadering van sewe sinodes. Die vraag is egter waarom die aard van die Semi-Pelagiaanse stryd soveel anders was. Die antwoord is te vind in die aard van die deelnemers aan hierdie stryd: die unieke karakter van die Galliese Kerk, die invloede van die kloosters en die besondere politieke klimaat van die gebied. Johannes Cassianus, die stigter van die kloosters in Marseilles, het die standpunt gehuldig dat die genade van God wat aan alle mense aangebied word, deur die mens se vrye wil aanvaar of verwerp kan word. Kort daarna het dieselfde sienings hulle verskyning vanuit die klooster op die eiland Lerins gemaak. Augustinus het op versoek van Prosper van Aquitaine deur middel van verskeie traktate tot hierdie debat toegetree. Ondertussen was die biskoppe van Arles en Viennes in 'n kerklike stryd gewikkel om hulle onderskeie bisdomme bo die ander verhef te kry - 'n tipiese verskynsel in die kerklike en politieke lewe van die suidelike deel van Gallië in daardie tyd. In 529 het Caesarius, die biskop van Arles, afkomstig uit 'n adellike familie en voorheen 'n monnik in die klooster van Lerins, 'n sinode in Orange byeengeroep. Hierdie sinode het 'n verswakte vorm van Augustinus se leer oor genade en die wil van die mens aanvaar. Caesarius was grootliks verantwoordelik vir die formulering van die sinodebesluite en al die elemente van die aard van hierdie dogmatiese stryd het in sy persoon saamgetrek.

\section{Inleiding}

Die kwessie oor sonde en die genoegsaamheid van God se genade by die verlossing van die uitverkorenes is 'n kernpunt in die gereformeerde leer. Die geskiedenis van die vorming van hierdie leerstuk word gekenmerk deur stryd. Augustinus was by talle kontroverse betrokke, waarvan die Pelagianisme sekerlik die belangrikste was. Hy het sonder skroom die Pelagiane ketters genoem en streng met hulle gehandel. Die Vandale se verowering van Numidië en Afrika het die stryd rondom die leer van Augustinus oor die genoegsaamheid van God se genade egter na Gallië laat verskuif. 'n Aantal teoloë daar het die leer van Pelagius ten volle verwerp, maar slegs 'n gedeeltelike waardering vir Augustinus se leer gehad. Hulle het die erfsonde erken, maar die noodsaaklikheid van die genade van 
God gereduseer tot 'n hulp (adiutorium) vir die mens se keuse. Hulle was van mening dat die genade wat almal nodig het en wat aan almal aangebied word, deur die mens verwelkom en aanvaar kan word deur die optrede van sy eie wil. lemand wat nog nie gedoop is nie, is sonder genade. So 'n persoon kan egter 'n ernstige begeerte hê om gedoop te word. Dan is die mens nie gesond (soos Pelagius beweer) en ook nie dood (soos Augustinus beweer) nie, maar siek aan 'n ellende wat die mens nie self kan genees nie, hoewel so 'n persoon die geneesmiddel self kan begeer en sy eie kan maak. Die uitverkiesing en die onweerstaanbaarheid van die genade (gratia irresistibilis) soos Augustinus dit geleer het, was na die mening van die aanhangers van hierdie leer te skerp en hy het na hulle mening ook van die tradisie van die kerk afgewyk (Rainy, 1902:487-488). Die stryd teen hierdie dwaalleer het sy hoogtepunt bereik toe Augustinus se leer in verswakte vorm deur die Tweede Sinode van Orange in 529 bevestig is. Caesarius, die biskop van Arles, was by hierdie geleentheid die voorsitter. Hoewel die besluite van hierdie sinode besonder gewig gekry het toe dit deur Pous Bonifacius II in 531 goedgekeur is, het dit 'n sentrale agendapunt van die teologie in die Weste gedurende die Middeleeue gebly en selfs nog gedurende die Reformasie en daarna sporadies stryd veroorsaak (Walker, 1986: 211). Die stryd rondom die Arminianisme en die ontstaan van die Dordtse Leerrëels is sprekende bewys daarvan.

Die Pelagiaanse stryd wat die Semi-Pelagiaanse stryd voorafgegaan het, is gekenmerk deur die betrokkenheid van baie prominente persone, soos Pous Innocentius I (402-417) en Zosimus (417-418), Keiser Honorius en verskeie biskoppe. By sewe konsilies in die Ooste en Weste, naamlik Kartago in 411, Jerusalem en Diospolis in 415, Milaan en Kartago in 416, Rome in 417 en Kartago in 418, is dit ter tafel geneem. Augustinus was egter net vir 'n kort tydperk (van ongeveer 429 tot met sy dood in Augustus 430) by die SemiPelagiaanse kwessie betrokke, en slegs op versoek by wyse van korrespondensie. In teenstelling met sy houding teenoor die Pelagiane het hy die Semi-Pelagiane nie as ketters beskou nie, maar hulle steeds as broers behandel. Die stryd het egter eers ná sy dood werklik in intensiteit toegeneem en die saak is uiteindelik hoofsaaklik beperk tot die suidelike deel van Gallië waar 'n enkele sinode daaroor aan die begin van die sesde eeu besleg het. Dié kontrovers is egter gekenmerk deur 'n bitter stryd. Die oorsaak daarvan kan ongelukkig nie net by die betrokkenheid van 'n bepaalde prominente persoon/persone/konsilies gesoek word nie, maar veral by die eie karakter van die Galliese Kerk in die vyfde en sesde eeu. 
Die vraag is waarom hierdie stryd juis in soveel felheid in die suide van Gallië gewoed het, veral in die lig daarvan dat Augustinus hulle nie so streng behandel het as wat die geval met die Pelagiane was nie. Hierdie vraag word beantwoord deur eerstens te bepaal of die kerk in Gallië 'n eie unieke karakter vertoon het wat aan die SemiPelagiaanse stryd 'n besondere intensiteit gegee het en tweedens deur te kyk na die staatkundige toestande in Gallië en die invloed daarvan op die kerk en hierdie dogmatiese stryd.

\section{Die besondere karakter van die Galliese Kerk in die vyfde en sesde eeu}

\subsection{Die monastiese invloed vanuit die Ooste - Johannes Cassianus}

Die kloosterwese is die een enkele aspek in die geskiedenis van die Galliese Kerk wat die belangrikste rol gespeel het by die opkoms van die Semi-Pelagianisme. Die kloosterwese het in die vyfde en sesde eeu groot momentum in die suide van Gallië gekry. Die belangrikste rede daarvoor was die invalle van die Germane wat nie net die staatkundige bestel nie, maar ook die kultuur bedreig het. Anders as wat die geval in Noord-Afrika was, het die kloosterwese in die suide van Gallië van die begin af uit die Oosterse asketiese tradisie geput (Rousseau, 1978:87 en Weaver, 1996:73). In Gallië was die kloosters egter nie selfonderhoudende asketiese sentrums soos in die Ooste nie. Hulle het eerder sentrums geword vir die uitdra van die Christendom, geleerdheid en kultuur (Mohrmann, 1961:164). Om hierdie rede het dit besondere aansien aan 'n civitas en sy biskop verleen indien daar 'n klooster binne die grense van die stad was.

Die plek waar die eerste klanke van die Semi-Pelagianisme gehoor is, was juis in 'n klooster in Marseilles. Die leer van die onvrye wil en die strewe na volmaaktheid in hierdie lewe is in elk geval 'n moeilik bruikbare dogmatiese uitgangspunt vir askese indien 'n mens enige verdienste aan jou eie werke wil toeken (Markus, 1990:63). Die eerste klooster in Marseilles is in ongeveer 415 gestig deur Johannes Cassianus (360-435), 'n dissipel van Evagrius Ponticus. Hy het reeds op jeugdige leeftyd kennis gemaak met die kloosterwese in die Ooste en in 400 ontvang hy die wyding tot die diakonaat van Johannes Chrusostumos en word ook later presbiter. Bedenkinge oor Johannes Chrusostomos se ortodoksie oor die leer van genade is verskeie kere uitgespreek (Bakhuizen van den Brink, 1979:179). Bright (1880:liii) sê byvoorbeeld dat Chrusostomos "Semi-Pela- 
giaanse taal" gebesig het, hoewel Kenny (1960:29) maan dat 'n mens hom nie ongenuanseerd 'n Semi-Pelagiaan moet noem nie.

In 405 gaan Cassianus na Rome waar hy onder andere vir Pelagius, wat self 'n tyd lank in 'n klooster deurgebring het, ontmoet. In 410 vestig hy hom in Gallië waar hy in 415 'n klooster vir mans en later een vir vroue in die hawestad Marseilles stig. Biskop Castor van Apta Julia, op wie se versoek Cassianus ook daar 'n klooster stig, versoek hom om sy idees oor die kloosterwese op skrif te stel. So sien sy De Institutis Coenobiorum et de Octo Principalium Vitiorum Remediis Libri XII in ongeveer 424 die lig. Cassianus wou egter ook graag die asketiese leerstellings van die verlede, en veral soos hy dit in die Ooste beleef het, op skrif stel en voltooi teen 429 sy Collationes Patrum, wat hy onder andere opdra aan Honoratus, die ab van die klooster op Lerins. So het hy 'n lang-gekoesterde ideaal bereik: die inwoners van die kloosters kon nou lees van asketisme en nie langer net staatmaak op mondelinge oorlewerings nie (Wallace-Hadrill, 1983:7). Dit word 'n klassieke werk en 'n belangrike leesbron vir monnike in die Weste (Lawrence, 1984:11).

Dit was in hierdie tyd dat Augustinus se leer oor die genade en die mens se wil 'n groot impak in die Westerse Kerk begin maak het. Cassianus verwerp die leer van Pelagius en Coelestius, maar kon hom nie versoen met Augustinus se leer oor die onweerstaanbaarheid van die genade, God se wil om slegs sommige te red en die dood van Christus alleen vir die uitverkorenes nie. Dit was vir hom in stryd met die oorlewering van die leer van die Oosterse Kerk wat hy veral uit die mond van Chrusostomos ontvang het. Veral in die dertiende collatio, met die opskrif De protectione Dei, maak Cassianus dogmatiese uitsprake wat later as "Semi-Pelagiaans" bestempel sou word.

Die moontlikheid dat die wortels van hierdie leer hoofsaaklik in die Ooste met sy Griekse inslag lê, word versterk deur die feit dat behalwe in Marseilles waar Cassianus gevestig was, Grieks nêrens elders in Gallië amptelik in die kerk of in die kloosters gelees en gebruik is nie (Laistner, 1931:25; Schwabe, 1967:478). Hoewel Grieks nie sy moedertaal was nie, het Cassianus dit vloeiend gepraat en was die bronne van die Griekse Vaders vir hom toeganklik. Sy werke getuig daarvan dat hy Griekse tekste gelees het (Stewart, 1998:36). Hy het ook dikwels na die Griekse teks van die Nuwe Testament verwys om die Latynse vertaling toe te lig. Hy het onder andere woordeliks uit 'n preek van Chrusostomos aangehaal. In sy Collationes gebruik hy aanhalings uit Hermas se Pastor om sy siening oor die vrye wil van die mens te ondersteun en hy haal ook 
dikwels uit Origenes aan (Courcelle,1969:225-232). Cassianus se rol in die Galliese Kerk van sy tyd kan dus nie onderskat word nie juis vanweë se verbondenheid met die Griekse bronne. Lerins en Marseilles het uiteindelik die hoofsentra van hierdie Oosterse invloede geword (Dawson, 1950:49). Toe die Germaanse invalle begin, het talle biskoppe en ander geestelikes na die kloosters in Marseilles gevlug omdat hulle dit as die veiligste plek in Gallië beskou het. Die groot aantal prominente kerkleiers wat 'n hele aantal jare daar deurgebring en later weer na hulle onderskeie tuistes teruggekeer het, het die invloed van Johannes Cassianus se leerstellings oor 'n groot gebied versprei (Holmes, 1911:293).

\subsection{Die betrokkenheid van Augustinus}

Die eerste reaksie teen Cassianus se uitsprake kom uit die pen van Prosper Tiro van Aquitaine (390-463). In 426/427 skryf hy 'n brief aan 'n vriend van hom, Rufinus, wat navraag gedoen het oor kritiek teen Augustinus se leer wat die rondte gedoen het. Kort daarna kry die monnike in Marseilles Augustinus se De Correptione et Gratia onder oë. Toe Prosper sien watter hewige (negatiewe) reaksie dit by hulle uitlok, nader hy en later ook sy vriend Hilarius, wat eweneens 'n aanhanger van Augustinus was, die skrywer daarvan. Ongeveer tien jaar na die laaste sinode van Kartago die Pelagianisme finaal besweer het, bereik hulle brief Augustinus waarin hulle hulle kommer uitspreek oor hierdie soort Pelagiaanse leer wat verkondig word. Hulle versoek hom om hulle leiding te gee, waarskynlik omdat nie een van hulle ampte in die kerk of in 'n klooster beklee het nie.

Augustinus reageer onverwyld op hierdie briewe deur in 429 twee werke te skryf: De Praedestinatione Sanctorum en De Dono Perseverantiae wat hy aan Prosper en Hilarius opdra. Augustinus neem die saak in alle erns op, maar behandel die skuldiges tog nog as broers en nie as ketters (soos in die geval van die Pelagiane) nie (Thiersch, 1889:209). Na Augustinus se dood in 430 skryf Prosper 'n verdediging van sy leermeester, naamlik Pro Augustino Responsiones ad Excerpta Genuensium na aanleiding van 'n brief wat hy van twee priesters uit Genoa ontvang. Omdat hy 'n meer gesagvolle opinie wou bekom om sy eie argumente te versterk, begewe hy hom, vergesel van sy vriend Hilarius, na Rome om Pous Coelestinus I te probeer oorreed om in te gryp. Die pous reageer met sy Epistula 21 ad Episcopos Gallorum. Hierdie brief is egter dogmaties so vaag dat die bal maar weer in Suid-Galliese hande is. $\mathrm{Na}$ sy terugkeer tree Prosper in die stryd met Johannes Cassianus met sy De gratia Dei et libero Arbitrio Liber contra Collatorem waarin hy 
Cassianus se Collatio XIII punt vir punt antwoord. Prosper skryf daarna nog vier geskrifte in antwoord op teenstanders van Augustinus se leer en gaan vestig hom uiteindelik in Rome. Cassianus sterf ook kort daarna, in 435.

Die intensiteit van die stryd neem hierna af, maar soos Weaver (1996:69) aantoon, het die Galliese monikke steeds vasgehou aan die gesagvolheid van die Griekse, Oosterse bronne terwyl hulle hulself vir 'n tydperk in die Latynse Weste bevind waar plaaslike lojaliteit en visie al hoe meer aan die orde van die dag is. Soos wat die tyd aanstap, het die tradisie wat Augustinus geskep het, al hoe meer vastrapplek en status gekry.

\subsection{Semi-Pelagiaanse stemme uit Lerins}

Die volgende Semi-Pelagiaanse geskrifte maak hulle verskyning vanuit die klooster op die eiland Lerins. Hierdie klooster is ongeveer vier kilometer van Cannes af geleë en is kort na die kloosters van Cassianus in Marseilles deur Honoratus (oorlede in ongeveer 429) gestig - pas na sy terugkeer van 'n pelgrimstog na die Ooste. Die klooster sou beroemd word as 'n sentrum vir geleerdheid en berug vir sy Semi-Pelagiaanse sentimente en uitgesproke vyandigheid teen Augustinus se leer oor die predestinasie. Cassianus se Institutiones en Collationes het ' $n$ groot invloed op die aard en karakter van hierdie klooster gehad (Weaver, 1996:106). Omdat ' $n$ groot aantal manne uit die aristokrasie van Gallië daarheen gegaan en later biskoppe geword het, kan die invloed van hierdie klooster moeilik oorskat word (Bright, 1880:Ixi). Honoratus wat later biskop van Arles geword het, het 'n groot invloed op die kerk van sy tyd gehad en talle biskoppe van Gallië het hulle onderrig van hom ontvang.

In ongeveer 434 skryf Vincentius van Lerins sy Commonitorium. Hy was van geboorte 'n Galliër wat op Lerins monnik en later ook priester was. Hy is in ongeveer 450 oorlede. Schmidt (1891:1054) sê dat dit baie maklik is om te bewys dat sy houding teenoor Augustinus vyandig was: in die geskiedkundige deel van die geskrif noem hy talle belangrike kerkleiers by die naam, bestempel die Pelagiane as gevaarlike ketters, maar hulle grootste bestryder, Augustinus, word nie een keer vermeld nie.

Faustus van Riez word deur Wagenman (1891:477) as die belangrikste literariese verteenwoordiger van die Semi-Pelagianisme genoem. Hy is aan die einde van die vierde of begin vyfde eeu gebore en sterf in die jaar 491. Hy word ab in die klooster op Lerins 
juis in die tyd toe Vincentius sy Commonitorium die lig laat sien. In 462 word hy biskop van Riez. Hy was ook betrokke by ander dogmatiese strydkwessies, soos teen die Ariane, Nestoriane en Monofisiete. Sy toetrede tot die Semi-Pelagiaanse stryd begin in 474 toe Lucidius, 'n presbiter van Riez, die leer van Augustinus oor genade en voorbeskikking propageer. Faustus tree eers met hom in gesprek om hom daarvan te laat afsien, maar rig uiteindelik ' $n$ brief aan hom in die naam van 'n aantal Galliese biskoppe waarin hy hom die "suiwere katolieke leer" voorhou: 'n middeweg tussen die ketterse uiterstes van Pelagius aan die een kant en Augustinus aan die ander kant. Eers nadat die Sinode van Arles van 475 onder leiding van Biskop Leontius, waaraan Faustus ook deelgeneem het, die sogenaamde error praedestationis verwerp, herroep Lucidus sy leringe in sy Libellus ad Episcopos. Faustus gaan egter voort om in opdrag van die sinode van Arles (457) en van Lyon (476) sy eie menings oor die strydvraag verder te ontwikkel. Hy doen dit in sy geskrif De Gratia Dei et Humanae Mentis Libero Arbitrio waarin hy nie net die Pelagianisme en die voorverordinering verwerp nie, maar self verder in Semi-Pelagianisme verval deur die uitverkiesing te reduseer tot 'n voorkennis van God en die mens die inisiatief toesê as dit by sy verlossing kom. Dit het baie onrus veroorsaak en is 'n hele aantal jare na sy dood finaal as afwykend van die katolieke leer verklaar (Farrelly, 1964:100-101). Hoewel Faustus op verskeie plekke in Gallië as heilige vereer is, het pous Hormisdas op 13 Augustus 520 verklaar dat hy nie onder diegene behoort wat as vader van die katolieke geloof erken word nie.

\section{Die besondere staatkundige omstandighede waarbinne die Galliese Kerk bestaan het}

Die sesde eeu staan uit as een van die betekenisvolste oorgangstye in die geskiedenis van die mensdom. Dit is 'n eeu waarin die sogenaamde Antieke Tyd oorgegaan het in die Middeleeue en Rome voor die Germane moes swig. Die suidelike deel van Gallië skep 'n boeiende prentjie van 'n bevolking wat verbasend Romeins in karakter gebly het ten spyte van die opeenvolgende oorheersing van die Boergondiese, Visigotiese, Ostrogotiese en Frankiese konings (Beck, 1950:xvi). Hierdie deel van Gallie het, omdat dit in voortdurende kontak met Rome, Ravenna en die Oostelike deel van die Middellandse Seegebied gebly het, inlywing by die Germaanse wêreld langer weerstaan as die res van Gallië (Klingshirn, 1994:3).

Die Galliese Kerk het 'n eie besondere karakter vertoon. 'n Mens kan selfs van die "Gallies-Romeinse Kerk" praat in teenstelling met 
byvoorbeeld die Kerk in Afrika. Tog is die karakter van die Galliese Kerk juis nie te vind in een besondere eienskap wat vir die provinsie in geheel geld nie, maar juis in 'n ryke verskeidenheid en dikwels ook botsende dele binne die een geografiese eenheid. Nog lank voor die invalle van die Germane was daar al 'n merkbare genuanseerdheid binne die Galliese Kerk te bespeur. 'n Mens kan die Gallies-Romeinse kerke inderdaad Christelike gemeenskappe en sosiale sentrums noem wat ingebed was in die stede, bewus van hulle afsonderlike geskiedenisse en hulle afsonderlike identiteite. Wanneer hulle uitsprake gemaak het, het hulle dadelik hulle geneigdheid tot verskille verraai (Wallace-Hadrill, 1983:1-16). Die rede daarvoor is drieërlei: eerstens was sommige kerke baie bewus van hulle unieke historiese oorsprong uit die dae van die Christenvervolgings (soos Lyon en sy biskop Irenaeus), tweedens was daar sommige jonger kerke wat aansien geniet het weens keiserlike betrokkenheid, soos Arles en Trier, en derdens was sommige kerke baie ryk, terwyl ander weer arm was.

Die feit dat die grense tussen die politieke en kerklike bakens so vaag was, het tot gevolg gehad dat die verskillende bisdomme in 'n groot mate op individualistiese wyse gefunksioneer het. Selfs die gebruik om in konsilies te vergader, kon nie daarin slaag om die nodige eenheid te bewerkstellig nie. Daar was eenvoudig nie genoegsaam gemeenskaplike probleme en ander sake waaroor daar gepraat kon word nie. Die enigste rede waarom daar nie ernstige skeurings plaasgevind het soos dikwels in die Oosterse Kerk gebeur het nie, was die mate van samebinding wat bewerkstellig is deur die uitsluitlike gebruik van Latyn deur die kerk en die gesentraliseerde godsdienstige mag van Rome (Mohrmann, 1961:158). Skeuring het nie plaasgevind nie, maar spanning was daar dikwels (Jones, 1964:873).

Die invalle van die Germane het die individualistiese tendens tussen die verskillende bisdomme nog verder versterk. Die verskillende stede het al hoe meer op hulself aangewese geraak om hulle eie oorlewing en die bewaring van hulle eie identiteit te bewerkstellig. Die inwoners van die stad, omring deur 'n stadsmuur met sy territorium daarrondom, was nou die sosiale eenheid met 'n eie identiteit en sy eie doelwitte. Die middeleeuse siening van die Christendom was dat dit polities pluralisties is, anders as wat in die ouer bronne geskets word (Daly, 1970:2).

Dit is baie moeilik om die sosiale, politieke, ekonomiese en godsdienstige aspekte van hierdie verskynsel uit mekaar te haal. Die rede hiervoor lê in die rol van die biskop. Die politieke en kerklike 
geografiese grense het in hierdie tyd grootliks ooreengekom (Klingshirn, 1985:23). In elke civitas is 'n bepaalde dorp as hoofdorp aangewys waar die plaaslike regering gesetel was en wat ook die setel van die biskop geword het. Die Romeinse politieke struktuur het met die invalle van die Germane en die val van Rome ineengestort. Die aangewese persone om daardie leemte te vul, was die biskoppe van die verskillende stede. Hulle het eenvoudig die rol van die Romeinse amptenary in die civitas oorgeneem. Daniel-Rops (1963:182) sê dat die biskoppe die enigste bastions was wat in staat was om die slagting van die Germane te weerstaan. Die chaos van die ineenstorting van die Romeinse Ryk was 'n geleentheid vir die kerk. Die kinderlike onkunde van die Germane was 'n voorbereiding vir die triomf van die priester (Fisher, 1955:175). So het die biskop nie net 'n leiersrol oorgeneem nie, maar ook opgetree as die bewaarder van 'n eie identiteit van die civitas. Die kerk is beskou as die instrument waarmee hierdie doel bereik kon word.

Die amp van biskop het om hierdie rede 'n besondere status begin kry en ongelukkig die ambisie geword van geleerde manne uit families met sosiale status. Namate die Romeinse beheer oor Gallië in die vyfde eeu afgeneem het, het die kanse vir lede van die aristokrasie al hoe minder geword om enigsins 'n belangrike pos in die keiserlike staatsdiens te beklee. Dit het tot gevolg gehad dat toelating tot en bevordering in die kerklike hiërargie al hoe meer die strewe van ambisieuse aristokrate geword het. Die groot aantal manne uit hierdie sosiale klas wat van sy stigting af na die kloostereiland Lerins gekom en vandaar af as biskoppe aangestel is (soos Honoratus en Hilarius van Arles, Lupus van Troyes en Faustus van Riez), is sprekend van hierdie tendens (Klingshirn, 1994: 20). Baie kerkamptenare het die amp van biskop gesien as 'n posisie wat in vele opsigte die moeite werd was om na te streef. Immers, 'n biskop was meermale die magtigste aristokraat in die civitas. Daarbenewens het hy beheer oor die rykdomme van die kerk gehad en sy magte het ook die aanstelling en beheer oor die klerici onder hom ingesluit. Al hoe meer manne het na die amp van biskop gestreef - boonop was dit 'n lewenslange amp. Dit het tot gevolg gehad dat die getal vakante bisdomme min en die kompetisie daarvoor fel was.

Biskoppe was nie altyd geneë met die verkiesing van 'n bepaalde kollega in 'n naburige vakante bisdom nie en was uiteraard nie altyd geneë om so 'n gesag te aanvaar nie (Jones, 1964:889-890). In 417 en weer in 500 het die Pous juis Arles bo Viennes gestel om onder andere onreëlmatighede en spanning rondom die verkiesing van 
biskoppe te probeer hokslaan (Chadwick, 1967:242). Simonie het ook aanleiding gegee tot spanning in en buite bepaalde bisdomme. Caesarius verwys na hierdie onheilsame praktyk in een van sy preke (Sermo, 110:1) oor die opstand van Korag teen Moses (Num. 16):

Dit wat daardie hooghartige Leviete moes deurmaak omdat hulle die priesteramp sonder die bevel van die Here begeer het, sal diegene wat die amp van biskop, priester of diaken deur middel van omkopery of vleiery probeer verkry het, ook moet verduur. ${ }^{1}$

Die Galliese biskoppe van die sesde eeu was besonder vry van eksterne beheer. Die aartsbiskop het sy posisie grootliks verkry op grond van die grootte en belangrikheid van sy civitas. Die invalle van die Germane het egter 'n groot verandering in die relatiewe belangrikheid van die verskillende stede teweeggebring (Dill, 1966:482). Die invloed van die keiser het in hierdie streek met die invalle al hoe meer afgeneem. Teen 476 was feitlik die hele Gallië in Germaanse hande en die plaaslike invloed en krag van die kerk het al hoe duideliker geword. Veral drie biskoppe het in hierdie tyd sterk na vore getree: Germanus van Auxere, Sidonius Apollinaris en Caesarius van Arles. Hierdie onderliggende spanning op grond van die staatkundige faktore wat daar tussen die verskillende bisdomme bestaan het, was 'n ongesonde teelaarde vir enige stryd - veral 'n dogmatiese stryd in 'n kerk waar daar alreeds nie 'n gesonde mate van samebindende krag was nie.

\section{Caesarius van Arles: die kulminasie}

Bykans al bogenoemde karaktertrekke van die Semi-Pelagiaanse stryd in die suide van Gallie trek saam in die een persoon onder wie se leiding dit tot 'n einde gebring is: Caesarius, die biskop van Arles en aartsbiskop van Gallië. Hy kom uit 'n adellike familie, bring die eerste aantal jare van sy lewe in die klooster van Lerins deur en bevind hom van die begin van sy biskopskap af betrokke in die stryd oor die leierskap tussen Arles en Viennes in die suide van Gallië. Hy was die stigter van twee kloosters in en naby Arles en die outeur van kloosterreëls vir mans en vroue. Hy het sy eie suster vir

1 Quod ergo pertulerunt superbi illi levitae, qui domino non iubente sibi sacerdotium vendicabant, hoc patiuntur quicumque se aut ad episcopatus aut ad presbyteratus vel diaconatus officium aut muneribus aut adulationibus impudenter conantur ingerere. (CC 103:456.) 
opleiding na 'n klooster gestuur wat deur Cassianus gestig is. Hy was 'n ywerige prediker en die skrywer van 'n werk oor die kwessie van genade en die vrye wil: Opusculum de Gratia. In sy preke en in genoemde werk oor genade kom sy teologiese posisie duidelik na vore: dit staan losweg in verhouding met sowel die wyse waarop Augustinus die kwessie oor genade verstaan het en die wyse waarop die mens se samewerking in sy verlossing in die kloosters in die suide van Gallië geleer is (Weaver, 1996:225). Wanneer die besluite van die Sinode van Orange in 529 neergepen word, is dit duidelik dat hy as voorsitter sy stempel deeglik daarop afgedruk het: die leer van die initium fidei wat in die vrye wil van die mens geleë is, word veroordeel sonder om Augustinus se leer oor die predestinasie te onderskryf.

\section{Gevolgtrekkings}

Die tydperk rondom die eeuwisseling van die vyfde na die sesde eeu was 'n onstuimige tydperk in die geskiedenis. Die invalle van die Germane het groot ontwrigting in die politieke en godsdienstige lewe in die Weste veroorsaak. Dit was 'n tyd van verminderde teologiese aktiwiteite, maar ook 'n tyd van 'n nuwe bedreiging van die waarheid oor God se genade en die mens se totale onvermoë om tot sy verlossing by te dra. Die Pelagiaanse stryd het in 'n gemuteerde vorm weer sy kop uitgesteek en 'n teelaarde gevind in 'n landstreek met unieke karaktertrekke wat ook in die kerklike lewe weerspieël is.

Dit het die Here behaag om juis in hierdie tyd en hierdie landstreek die waarheid oor sy eindelose genade te laat seëvier. Die SemiPelagiaanse stryd sou 'n totaal ander karakter gehad het indien dit elders in die Westerse Kerk sy ontstaan gehad het. Indien 'n sinode elders as in Orange 'n besluit oor hierdie saak moes neem, sou die leer oor die genade van God en die mens se sogenaamde vrye wil nie so helder uiteengesit gewees het nie. Daar bestaan 'n duidelike verband tussen die opkoms van die Semi-Pelagianisme en die bloei van die kloosterwese in die vyfde en sesde eeu in Gallië. Nêrens elders sou 'n mens binne die grense van een landstreek terselfdertyd soveel aanhang en verskille met Augustinus vind nie. Nêrens elders in die Weste was biskoppe en monnike in hierdie tyd meer betrokke by teologiese sake as in Gallië nie. Die invalle van die Vandale in Noord-Afrika het dáár 'n einde aan noemenswaardige teologiese aktiwiteite gebring. In Italië en Spanje, waar nuwe kloostergemeenskappe opgerig is, was die literêre arbeid beperk tot die skryf van kloosterreëls. In Gallië het Johannes Cassianus 'n beduidende rol gespeel in die ontstaan van die Semi-Pelagiaanse stryd 
deur die skryf van werke wat begaan was oor 'n asketiese lewe en die bereiking van volmaaktheid.

Die Semi-Pelagiaanse stryd in Gallië was ' $n$ weerspieëling van die noue band wat daar tussen die kerklike en staatkundige toestande in daardie tyd geheers het. Die individualistiese karakter van die verhouding tussen die verskillende bisdomme, geskoei op die lees van staatkundige afbakenings, het op die ou einde die intensiteit van en die emosie rondom die Semi-Pelagiaanse stryd verhoog. Die onsekerheid rondom die status van biskoppe wat saamgeval het met die soms vinnige verwisseling van Germaanse regeerders, het verder bygedra tot die suspisies oor dogmatiese suiwerheid wat daar onderling bestaan het. Onderlinge kompetisie tussen die biskoppe is vererger deur die afname van keiserlike betrokkenheid by die provinsies in Gallië en die gepaardgaande ineenstorting van die Romeinse administrasie. Die feit dat die biskoppe se posisie en aansien in die lig daarvan toegeneem het, het tot gevolg gehad dat hulle mekaar met 'n nog groter mate van jaloesie bejeën het, veral as dit by dogmatiese suiwerheid gekom het.

In teenstelling daarmee was die kerk in Italië in hierdie tyd gewikkel in 'n politieke stryd met Konstantinopel en die Oos-Gote en dit het in hierdie proses baie van sy teologiese en morele outoriteit verloor (Walker, 1986:213). Al hierdie elemente het uiteindelik saamgetrek in die persoon van Caesarius van Arles wat as voorsitter opgetree het by die Sinode van Orange in 529 wat finaal oor hierdie dogmatiese stryd moes handel. In hom as persoon sien ' $n$ mens duidelik hoe die Here sy kerk in die waarheid lei.

\section{Geraadpleegde bronne}

BAKHUIZEN VAN DEN BRINK, J.N. 1979. Handboek der kerkgeschiedenis. Deel I. Leeuwarden: De Tille.

BECK, H.G.J. 1950. The pastoral care of souls in South-East France during the sixth century. Rome: Universitatis Gregorianae.

BRIGHT, W. 1880. Select anti-Pelagian treatises of st. Augustine and the acts of the second council of Orange. Oxford: Clarendon.

CAESARIUS ARELATENSIS. Sermones. Turnholt: Brepols. (Corpus ChrisCC tianorum series Latina, 103 en 104.)

kyk CAESARIUS ARELATENSIS

CHADWICK, H. 1967. The Early Church. London: Cox \& Wyman.

COURCELLE, P. 1969. Late Latin writers and their Greek sources. Cambridge: Harvard University Press.

DALY, W.M. 1970. Caesarius of Arles, a precursor of Medieval Christendom. Traditio, 26:1-29.

DANIEL-ROPS, H. 1963. The church in the Dark Ages. London: Dent. 
DAWSON, C. 1950. Religion and the rise of Western culture. London: Sheed \& Ward.

DILL, S. 1966. Roman society in Gaul in the Merovingian Age. London: Allen.

FARRELLY, M.J. 1964. Predestination, grace, and free will. Westminster: Newman.

FISHER, 1955. A history of Europe. London: Arnold.

HOLMES, T.S. 1911. The origin and development of the Christian church in Gaul during the first six centuries of the Christian Era. London: Macmillan.

JONES, A.H.M. 1964. The later Roman Empire 284-602: a social, economic and administrative survey. Oxford: Blackwell.

KENNY, A. 1960. Was Chrysostom a Semi-Pelagian? Irish theological quarterly, 27:16-29.

KLINGSHIRN, W.E. 1985. Authority, consensus and dissent: Caesarius of Arles and the making of a Christian community in Late Antique Gaul. Stanford: Stanford University. (Ph.D. thesis.)

KLINGSHIRN, W.E. 1994. Caesarius of Arles: the making of a Christian community in Late Antique Gaul. Cambridge: Cambridge University Press.

LAISTNER, M.L.W. 1931. Thought and letters in Western Europe A.D. 500 to 900. London: Methuen.

LAWRENCE, C.H. 1984. Medieval monasticism: forms of religious life in Western Europe in the Middle Ages. New York: Longman.

MARKUS, R.A. 1990. The end of Ancient Christianity. Cambridge: Cambridge University Press.

MOHRMANN, C. 1961. Etudes sur le Latin des chrétiens. Volume 2: Latin chrétien et médiéval. Rome: Edizioni di storia e letteratura.

RAINY, R. 1902. The ancient Catholic church: from the ascension of Trajan to the fourth General Council (A.D. 98-451). Edinburgh: Clark.

ROUSSEAU, P. 1978. Ascetics, authority, and the church in the age of Jerome and Cassian. Oxford: Oxford University Press.

SCHMIDT, H. 1891. Vincentius van Lerinum. (In Patristisch-Biographisch woordenboek op de zes eeuwen de Christelijk kerk. Vol. 2. p. 1052-1063.)

SCHWABE, L., ed. 1967. Teuffel's history of Roman literature: the Imperial Period. Deel 2. New York: Franklin.

STEWART, C. 1998. Cassian the monk. Oxford: Oxford University Press.

THIERSCH, F. 1889. Johannes Cassianus. (In Patristisch-Biographisch woordenboek op de zes eeuwen de Christelijk kerk. Vol. 1. p. 205-210.)

WAGENMAN, R. 1889. Faustus van Reji. (In Patristisch-Biographisch woordenboek op de zes eeuwen de Christelijk kerk. Vol. I. p. 477-482.)

WALKER, W. 1986. A history of the Christian church. New York: Scribner.

WALLACE-HADRIL, J.M. 1983. The Frankish Church. Oxford: Clarendon.

WEAVER, R.H. 1996. Divine grace and human agency: a study of the SemiPelagian controversy. Macon: Mercer University Press.

\section{Kernbegrippe:}

Galliese Kerk

genade

semi-Pelagianisme

vrye wil 


\section{Key concepts:}

free will

Gaulish Church

grace

semi-Pelagianism 
